\title{
Differing Interpretations: Causes of the Collapse of the Soviet Union
}

\author{
Antony Kalashnikov
}

\begin{abstract}
This historiography paper analyzes a sample of the body of writing regarding the causes of Soviet collapse that has appeared in the last 20 years. There are several themes that the time-period's histories address, but, for the most part, they conveniently tend to focus on the central question of "why did the Soviet Union collapse?" As most secondary sources tackle the question directly and coherently, this essay will argue that historiography is best classified by 'factors of collapse'. Furthermore, this essay will contend that there is a correlation between mediums of writing and the 'factor of collapse' they tend to espouse.
\end{abstract}

\section{Introduction}

On December 31, 1991, the Union of Soviet Socialist Republics ceased to exist. Amazingly, the Soviet Union's collapse was completely unanticipated; the rapid unravelling of events in its last six years seemed to take by surprise its citizens, leaders, and world observers. As late as the mid1980's, when the inadequacies of the Soviet system vis-à-vis the capitalist world became increasingly apparent, few predictions of the state's impending collapse were made. ${ }^{1}$ Only after the rapid fall of socialist regimes in Eastern Europe in 1989 did the future of the Soviet Union come under scrutiny and serious doubt. With the abandonment of the socialist system and the disintegration of the Union, people became increasingly preoccupied with coming to terms and understanding the USSR's collapse, which left a set of questions both particular and general. For political scientists, it held drastic implications for theories of empire, totalitarianism, central economic planning, multinational states, and international politics. The collapse also challenged historians to explain the closing chapter of Soviet history in a coherent, causal narrative. Ivory tower aside, the failure of the 'greatest socialist experiment' entailed severe, at times disorienting, repercussions for the political culture of the left. Perhaps most importantly, citizens and leaders of the USSR's successor states were immersed into a new reality in which they were forced to make sense of their 70-year-old Soviet heritage and history. Thus, interpretations of Soviet collapse have thrived (and continue to thrive) in a politically-charged, but nonetheless exciting, atmosphere.

This historiography paper will analyze a sample of the body of writing regarding the causes of Soviet collapse that has appeared in the last 20 years. There are several themes that the timeperiod's histories address, but, for the most part, they conveniently tend to focus on the central question of "why did the Soviet Union collapse?" This question will frame the structure of this historiography paper. In the absence of schools of thought which propose a singular cause for collapse, various writings tend to argue for the most important factor. As most secondary sources tackle the question directly and coherently, this essay will argue that historiography is best classified by 'factors of collapse'. Furthermore, this essay will contend that there is a correlation between mediums of writing and the 'factor of collapse' they tend to espouse. This paper will be organized accordingly: after examining the background events to the collapse of the

${ }^{1}$ Victor Kuznetsov, "The Economic Factors of the USSR's Disintegration," in The Fall of the Soviet Empire, ed. Anne de Tinguy (Boulder: East European Monographs, 1997), 264-265. 
Soviet Union, I will outline four 'factors of collapse' that the historiography organizes into economic, nationalities, political, and systemic. I will then analyze the tendencies of different mediums of writing: political science and historical studies, political memoires, journalistic accounts, and textbooks.

A preliminary point, however, needs to be established - namely, the meaning of the concept of 'collapse' within the Soviet context. After all, it can be taken to mean the fall of the socialist system or the disintegration of the Union of 15 republics. In this essay, as in most other studies, 'collapse' will refer to the collapse of the political system in its totality, that is, both the federative state and the socialist regime within it.

\section{Historical Background}

In 1985, the Soviet Union was at a crossroads. Socially, politically, and economically it sported several successes, as a result of both its socialist system, and the objective resources of the largest and most diverse state in the world. Since its inception in the early 1920's, the Soviet Union had continuous economic growth (interrupted only during WWII); its society benefited from a slowly but steadily improving standard of living. ${ }^{2}$ Following the Second World War, it became a military and political superpower, a leader of the entire socialist bloc and the only real counter-balance to American hegemony. It had several achievements, such as free education and medical care, and a zero percent unemployment rate. Its scientific and cultural advances were universally recognized, everywhere from putting the first person in space to successes in ballet, chess, and hockey. The Soviet Union had also an official record of economic equality, with little stratification in both nominal and real income. ${ }^{3}$

At the same time, however, several problems faced the country. Corruption and nepotism ran rampant, threatening social stability, economic success, and popular support for the elite. ${ }^{4}$ Economic growth rates had started to stagnate, with crucial areas such as agriculture in a precrisis situation, affecting availability of consumer goods and lowering material standards of living. This was exacerbated by a crippling military budget as high as $20 \%$ of the GDP, which prevented investment into 'useful areas.' Political disengagement and apathy reached huge proportions, with little popular support for the dogmas of class struggle and other Marxist-Leninist precepts. The war in Afghanistan, being waged at a huge cost of resources and manpower, served to anger the population with the unreceptive and undemocratic political process and elites. ${ }^{6}$ The leadership, however, was corrupt, ultra-conservative, and preoccupied with maintaining their positions and the status quo. The average age of leading party members topped 70; many were ill, senile, and out-of-touch with modern realities. ${ }^{7}$

In 1985, following the deaths of his three predecessors within three years, the fifty-four year-old Mikhail Gorbachev became General Secretary of the Communist Party (CPSU). This year, in nearly all historiography, represents a major turning point in Soviet history, as Gorbachev's ideas and policies (and the changes they brought about) so glaringly broke with the previous regimes.

\footnotetext{
${ }^{2}$ David Kotz and Fred Weir, "The Collapse of the Soviet Union was a Revolution from Above," in The Rise and Fall of the Soviet Union, ed. Laurie Stoff (Farmington Hills: Thomson Gale, 2006), 157-158.

${ }^{3}$ Ligachev, Yegor. Kmo npedan CCCP? [Who Betrayed the USSR?] (Moscow: Algoritm Kniga, 2010).

${ }^{4}$ George J. Neimanis, The Collapse of the Soviet Empire: a View from Riga (Westport: Praeger Publishers, 1997$), 5$.

${ }^{5}$ Kuznetsov, "The Economic Factors of the USSR's Disintegration," 267.

${ }^{6}$ Saki R. Dockrill, The End of the Cold War Era: The Transformation of the Global Security Order (London: Hodder Education, 2005), 176-184.

${ }^{7}$ Jerry Smith, The Fall of Soviet Communism: $1985-91$ (New York: Palgrave Macmillan, 2005), 9.
} 
His first attempts at reform, however, were minor ones aimed at maximizing the potential of the system, not changing the system itself (for example, the unsuccessful anti-alcohol campaign). However, even as early as the $27^{\text {th }}$ Party Congress in 1986, Gorbachev began denouncing the 'stagnation' and 'negative tendencies' of the Brezhnev regime and thus reorienting the Soviet Union towards the (primarily economic) policy of acceleration. ${ }^{8}$ At around the same time Gorbachev also initiated a shake-up of the leadership (which involved appointing young, reformminded individuals to high positions), a tendency which persisted throughout the next five years. Among other things, the Chernobyl nuclear explosion on April $26^{\text {th }}$ signalled the degradation of the Soviet system - technological backwardness, a negligent attitude towards the environment and safety planning, and a lack of political responsibility - and hence the pressing need for further, more substantial change. ' Indeed, the Gorbachev leadership, frustrated with the incoherent results of acceleration, supported a move toward towards liberalization of both the economic and political sphere, which was to re-invigorate the country, involve the masses, and create a more humane and effective system of governance and life. This new direction was given coherence in the doctrines of perestroika (restructuring) and glasnost (openness). June 1987, for example, saw the first local multi-candidate elections launched (albeit at a local level), aimed at increasing political participation and democracy. ${ }^{10}$ Shortly afterwards, the socialist economy began to be liberalized by de-centralization and the formation of cooperative enterprises. However, the reforms tended to clash with the system of state planning, price control, and subsidies, resulting in perpetually increasing economic difficulties - which were in turn interpreted by the leadership as evidence of the need to further liberalize. ${ }^{11}$ On the political front, democratization created the opportunity for organized dissent and opposition, both against Marxist-Leninist postulates (the CPSU) and the Union government. It also escalated ethnic tensions, which became increasingly serious and detrimental to peace, beginning with riots (and later, civil war) in the Armenian-dominated enclave in the Azerbaijan SSR. ${ }^{12}$ In most cases, Moscow-imposed military rule did nothing but aggravate tensions and channel resentment towards the centre.

After 1988, with a deteriorating economy and increasing instability, faith in the Soviet system waned and it became increasingly apparent that the USSR was heading towards a crisis. Nationality started playing an increasing role in domestic politics as political infighting broke out between republics, autonomies, and the central government. Popular Front organizations were formed in the Baltic Republics (Latvia, Lithuania, Estonia), demanding sovereignty and, shortly after, independence. With the founding of the Congress of People's Deputies as a democratic Union-level assembly, parliaments (i.e. Soviets) in individual republics were transformed and democratized. ${ }^{13}$ Amid the fall of communist regimes in Eastern Europe, Gorbachev refused to interfere (by enacting the Brezhnev Doctrine) and preserve the Soviet Empire, which now faced terminal decline - demonstrating the USSR's international weakness.

\footnotetext{
${ }^{8}$ I. A. Adamova and I. M. Zinkova, ed., XXVII съезд КПСС о руководящей роли парии в ускорении развития страньг [27th Congress of the CPSU: The Leading Role of the Party in Accelerating the Country's Development] (Moscow: Moscow State University Publishing, 1988), 11.

${ }^{9}$ David Marples, The Collapse of the Soviet Union, 1985-1991 (Harlow: Pearson Education Limited, 2004), $20-24$.

10 Smith, The Fall of Soviet Communism: 1985-91, 114.

${ }^{11}$ Robert Knight, Stalinism in Crisis (London, Pluto Press, 1991), 15-21.

12 Edward W. Walker, Dissolution: Sovereignty and the Breakup of the Soviet Union (Oxford: Rowman \& Littlefield Publishers, 2003), 57.

13 J. S. Duncan, "The Collapse of the Soviet Union was a Revolution from Below," in The Rise and Fall of the Soviet Union, ed. Laurie Stoff (Farmington Hills: Thomson Gale, 2006), 147.
} 
In 1990, the Union itself began to fall apart, with Lithuania declaring independence first in March. ${ }^{14}$ Within a year, majority support for preserving the Union remained, but demands for sovereignty and decentralization were even higher. Generally, the people wanted a loose confederation of republics voluntarily delegating certain limited powers to the Union. Amid all these tumultuous changes that the Gorbachev leadership either spurred on or failed to deal with, 'conservative' Party members such as the heads of the Army and KGB took what they saw as the last chance to preserve the Soviet Union as it was. On August 19, 1991 they formed an unconstitutional Emergency Committee, placing Gorbachev on house arrest and proclaiming martial law. ${ }^{15}$ However, their lack of effective planning became quickly apparent as they failed to secure both popular support and endorsement from state bureaucracies; the coup fell in three days. The coup contributed to massive discontent with the Soviet Union and the Communist Party that skyrocketed by the end of the year, allowing the leaders of Russia, Ukraine, and Byelorussia to annul the Union in a semi-legal measure known as the Belavezha Accords. They instituted a loose Confederation of Independent States (it exists to this day, but in a largely ceremonial form) which replaced the Soviet Union on December 31, 1991.

\section{Historiographic 'split'}

These events, however, were interpreted in radically different ways by contemporaries and scholars. I would now like to talk about the historiographic 'split' around the question of why the Soviet Union collapsed. As mentioned above, I will argue that the historiography is best classified by 'factors for collapse', and that these are: economic, nationalities, political, and systemic. It is interesting to note that while most studies (textbooks being the notable exception) tend to opt for one factor as being most important in bringing about collapse, they don't argue it vis-à-vis others. On the contrary, they do not engage other standpoints, to the extent that it detracts from their arguments' persuasiveness, especially to a person acquainted with the historiographical background. Thus, it seems that within this topic, authors reach some pre-conceived opinion, and then substantiate it with sources, choosing not to demonstrate why it is this-and-not-that factor they opt for.

Studies which tend to bring out the economic factor focus on the USSR's crisis-ridden economy at the time of collapse. Though economic data/sources form the basis of the argument, to a large extent studies operate on theoretical level, interpreting the essentially undisputed facts. Thus, while intuitively one may expect a certain degree of unanimity amongst arguments which bring out the economic factor (due to the 'objectivity of numbers'), this is not the case. Actually, a great variety of approaches exist; their conclusions can be divided into two camps - the 'longterm economic factor' and the 'short-term economic factor'.

The political scientist Robert Knight's book, Stalinism in Crisis, is exemplary of the 'long-term economic factor' position. Knight claims that the flaws of the Soviet economic system, which was characterized by centralized planning, formalized under Stalin were never overcome, and accumulated over the decades. Development became harder and harder as modern economic activity demanded higher sophistication. ${ }^{16}$ Centralized planning agencies did not have the organizational capacity to regulate the huge economy; this impasse could only be resolved

\footnotetext{
${ }^{14}$ David Marples, "The Fall of the USSR: The National Dimension and the Role of Ukraine," in Tpагеdия Bеликой Аержавы [Tragedy of a Mighty Power], ed. G. N. Sevostyanov (Moscow: Sotsialno-Politicheskaya Misl Publishing, 2005), 541.

${ }^{15}$ David Remnick, Lenin's Tomb: The Last Days of the Soviet Empire (New York: Random House, 1993), 453-457.

${ }^{16}$ Knight, Stalinism in Crisis, 13-14.
} 
through the introduction of the market. ${ }^{17}$ It was impossible to reform the system gradually, as this only 'prolonged the pain' of shifting to a market. Fundamentally, this resulted in the complete break with the foundational institutions of the state. Thus, by focusing on the essential economic institutions of the Soviet system (ironically, he uses a Marxist analysis), Knight's argument is a fine example of studies espousing the 'long-term economic factor' of the USSR's collapse.

In contrast to this position, the economist Victor Kuznetsov's essay "The Economic Factors of the USSR's Disintegration" frames the cause of collapse in terms of the short-term economic dynamic. Kuznetsov concedes that the socialist economy had several systemic inefficiencies, including: low productivity of labour (due to lack of competition), slow progress of science and technology (due to over-centralization), and an excessive military expenditure. ${ }^{18}$ However, he claims that the Soviet economy, though somewhat wasteful, could still have provided for the reproduction of the socialist system, even if it would have fallen behind the capitalist one. After all, even according to Western estimates, growth in pre-perestroika USSR was still 'moderate' by world standards. ${ }^{19}$ The more important cause, rather, was circumstantial - arising from the unconsidered and hap-hazard reforms of the economy during perestroika. This included the "laws on socialist enterprises, on partial abolition of the foreign trade monopoly,... limited liberation of the price formation and wages, and [greater freedoms] to directors of public enterprises". ${ }^{20}$ These ultimately clashed with the socialist system of central planning and created economic chaos. Kuznetsov's style of argument is typical of studies which highlight the 'shortterm economic factor' of Soviet collapse. It is worthwhile to note, however, that in both longterm and short-term economic arguments, as in the above examples, the connection between an economic crisis and the collapse of the Union state structures (as opposed to the socialist system) is not directly explained and is frequently glossed over.

If 'economic factor' studies put the blame on the Soviet economy and track the collapse of socialism, a large massif of investigations brings out the nationalities factor as the reason for the disintegration of the Union state. In terms of sources, proponents of 'the nationalities factor' tend to focus on the policies and structures of Soviet federalism, as well as post-1985 political events between the republics and the center. From this approach as well emanate long-term and short-term variants of the 'nationalities factor' argument.

For instance, in his book Dissolution: Sovereignty and the Breakup of the Soviet Union, the political scientist Edward Walker looks at the long-term, abstract, and systemic factors of nationalseparatism's rise in the Soviet Union. He claims that dissolution was brought about not by popular demand, but rather by the structure of the Soviet 'ethno-federal' system and the legitimizing myths of the Soviet nationality policy. Though Walker concedes the particular events and personalities which triggered the collapse (economic turndown, counter-productive policies of the Union leadership, etc.), he argues that they couldn't have happened outside of the wider context of Soviet federal relations. The USSR, after all, was explicitly constructed as the 'voluntary union of republics'; its official Marxist-Leninist ideology, in rhetoric, endorsed national pride and self-determination. ${ }^{21}$ However, republics were de facto trapped in a centralized state, and their populations, to varying degrees, wanted 'out'. When the conditions became freer with

\footnotetext{
${ }^{17}$ Ibid. $12-13$.

${ }^{18}$ Kuznetsov, "The Economic Factors of the USSR's Disintegration," 264.

${ }^{19}$ Ibid, 265.

${ }^{20}$ Ibid, 275.

${ }^{21}$ Walker, Dissolution: Sovereignty and the Breakup of the Soviet Union, 21-48.
} 
perestroike and glasnost, republican politicians were able to effectively use the rhetoric and legitimizing myths of Soviet nationality policy against the Centre. Thus, according to views such as Walker's, the breakup of the Soviet Union was facilitated by its long-term federative structures and policies.

In contrast to this view, arguments like those of political scientist Z.A. Stankevitch posit that the breakup of the Soviet multi-national state was a result of short-term events. In the essay "The Relationship Between the Political and Nationalities Factors in the Fall of the USSR", he contends that the collapse occurred because of specific inadequacies on the part of the Union government in the late 1980's. Firstly, the central authorities failed to legislate in a flexible way to mediate and quell conflict between states of the USSR. ${ }^{22}$ Secondly, central authorities did not follow through with the execution of their decisions. ${ }^{23}$ Thirdly, central authorities acted too slow - always reactively, and failing to prevent future problems. ${ }^{24}$ Thus, his line of the 'short-term nationalities' argument contends that the ruling Soviet authorities failed to politically mediate national conflicts appropriately - a development which could have been avoided. This argument is bolstered by the historian S. V. Cheshko's analysis in the essay "The Role of Ethnonationalism in the Break-up of the Soviet Union", which demonstrates how nationalism was harnessed by local political elites to aggrandize their power - to the point of leaving the Union. ${ }^{25}$ In such a way, these types of studies illustrate the 'short-term nationalities factor' position. However, just as proponents of the 'economic factor' ignore the federative aspect of the USSR's collapse, 'nationalities factor' investigations tend to overlook the Soviet socialist regime and the material, economic context of the late 1980's.

Several studies try to bridge the divide between the economic and nationalities factors by shifting their focus to the political fountainhead from which both factors sprung. Indeed, both the economic collapse and the disintegration of the Union can be seen as political events determined by the leaders, events, policies, and structures of the USSR - key sources for proponents of the 'political factor'. Within this stream too, however, there is a division into long-term and shortterm approaches. Both consist of incredibly varied conclusions, and generalizing across cases is near impossible; their only similarity is the political focus. Perhaps one reason for this is that 'political factor' studies tend to be the most partisan, imputing political and ideological actors that are still alive and real.

Looking at one long-term political cause of collapse, political scientist Nick Bisley's The End of the Cold War and the Causes of Soviet Collapse, for example, claims that the gradual abandoning of international confrontation introduced massive problems into the Soviet political sphere. Indeed, confrontation provided, ideologically: legitimation of the state and the CPSU's control of it, justification for privations of Soviet life, a sense of purpose, and a source of prestige. ${ }^{26}$ Economically, it ordered value and worth in an essentially war-oriented economy. ${ }^{27}$ Politically, it

22 Z. A. Stankevitch, “Соотношение национального и политического факторов в процессе разрушения Союза ССР [The Relationship Between the Political and Nationalities Factors in the Fall of the USSR]," in Tpazeduя Bеликой Аержавы [Tragedy of a Mighty Power], ed. G. N. Sevostyanov (Moscow: Sotsialno-Politicheskaya Misl Publishing, 2005), 428-429.

23 Ibid, 431.

${ }^{24}$ Ibid, 431-432.

25 S. V. Cheshko, "Роль этнонационализма в распале СССР [The Role of Ethnonationalism in the Break-up of the Soviet Union]," in Трагедия Великой Aержавы [Tragedy of a Mighty Power], ed. G. N. Sevostyanov (Moscow: Sotsialno-Politicheskaya Misl Publishing, 2005), 466-467.

${ }^{26}$ Nick Bisley, The End of the Cold War and the Causes of Soviet Collapse (New York: Palgrave Macmillan. 2004), 59-60.

${ }^{27}$ Ibid, 60-61. 
contributed to organizing the political system and provided a means of structuring the convention-based hierarchy. ${ }^{28}$ However, confrontation, being a rising burden, sapped the resources of the Soviet Union, and couldn't be sustained indefinitely; its abandonment resulted in a subversion of elite cohesion, a degradation of social structure, and the loss of the socialist system's raison-d'être, which was essentially based on class struggle. Several other studies use a similar style of long-term analysis in examining the structure of the Soviet political system as the cause of collapse.

The 'short-term political factor' perspective, however, combats the view that the collapse of the Soviet Union arose out of its own structure (i.e. the self-destruction thesis). On the contrary, these studies argue that the Soviet Union could have endured much longer, in either an antiquated or reformed form. Consequently, they focus on the specific political leaders and policies in the post-1985 context which brought about the collapse. The principle opposing viewpoints blame either the 'right' (conservative) political figures/forces, 'left' (democratic) political figures/forces, or Gorbachev's inadequacy in dealing with both. Yegor Ligachev (the former leader of the CPSU's conservative faction), for example, in his book Who Betrayed the USSR? Ligachev blames the radical-democratic forces and Gorbachev's leadership style for collapse. He claims that the Soviet system was a viable and superior form of social organization which needed only limited reforms. Gorbachev, being largely incompetent and reactive in leading, fell under the influence of proponents of capitalism who destroyed the country for their own localist political and economic interests. Ligachev particularly blames the senior 'liberal' Party official Alexander Yakovlev and his clique for promoting destructive anti-socialist and antiUnion policies which ultimately led to collapse. ${ }^{29}$ Other 'short-term political factor' studies follow in the same style.

A much broader (perhaps even nebulous) line of argument found in historiography is that the collapse of the Soviet Union was due to the nature of 'the system'. Basically, this view represents a conflation of the above factors into a soupy mix which is taken to be the Soviet system. This approach is generally less academically rigorous; frequently, it is ahistorical and essentializing. Indeed, the features of the Soviet system are often defined in exclusively 'bad' terms and the approach seems to betray some sort of political bias.

In The Collapse of the Soviet Empire: A View from Riga, George Neimanis, a Latvian-American economist visiting the USSR in 1980s, espouses such a view. With the state of the economy "shabby, threadbare, faded, dilapidated, decrepit, and seedy," Neimanis writes, the entire legitimacy of Soviet rule rested on propaganda, lack of communication with the rest of the world, and state terror. ${ }^{30}$ When the resources for sustaining this were exhausted, the USSR was doomed to collapse. The book is written in a largely synchronic way, jumbling together the entire Soviet era for the purpose of a politicized, indicting message against both the Russian-controlled Union and communism. In several respects, it is illustrative of the argument that the Soviet Union collapse due to 'the system', which was unviable and corrupt.

\section{Mediums of Writing}

So far, this essay has classified historiography by 'factors of collapse' - economic, nationalities, political, and systemic. I would now like to point out a general correlation between mediums of

\footnotetext{
${ }^{28}$ Ibid, 61-62.

${ }^{29}$ Ligachev, Kmo npedan CCCP? [Who Betrayed the USSR?], 89-132.

${ }^{30}$ George J. Neimanis, The Collapse of the Soviet Empire, 8.
} 
writing and the 'factor of collapse' they tend to espouse. I will examine the tendencies of political science and historical studies, political memoires, journalistic accounts, and textbooks.

Studies coming from the political science background usually develop broad, theoretical, and long-term perspectives in analyzing the collapse of the Soviet Union. This is true in terms of economic, nationalities, and political factors. Often, it seems that the author tries to generate some kind of law, or at least draw implications/generalizations to the field of politics. This tendency is perhaps intensified by the nature of the Soviet Union - an unprecedented experiment in socialism, central planning, and multinational federalism - which serves to attract political analysis. For example, the political scientist Stephen E. Hanson, in his essay "Gorbachev: The Last True Leninist Believer", uses the Weberian analytic method to look at the political dimensions of collapse. Drawing upon Max Weber's characterization of modernity, domination, and legitimacy, Hanson examines the patterns of Soviet history in abstract, theoretical terms (and mind-bending jargon). According to him, Leninist ideology married rational and charismatic elements to implement a "charismatic impersonal" form of modernity and social structure. ${ }^{31}$ Collapse allegedly came about as the natural end of its self-reinventing progression, which could not be constrained to a Leninist form. In such a way, political science studies have a tendency to focus on long-term, abstract causes of Soviet collapse.

Historical studies, by contrast, tend to focus more on short-term causes of collapse, whether in economic, nationalities, or political themes. Perhaps this is a function of causation being harder to prove over the long-term, and historians being wary of being criticized of epistemological idealism. Accordingly, the historical investigation "The Collapse of the Soviet Union was a Revolution from Above," done by David Kotz and Fred Weir, focuses on the immediate causes of collapse. Namely, they argue that in the 1980's, Soviet elites spurred on the transition to capitalism, from which they could gain substantially. This is evidenced by their endurance in positions of economic and political power in the post-USSR order. ${ }^{32}$ In actuality, the masses desired some form of socialism or social-democracy, not the type of laissez-faire economics that stepped in following the collapse. ${ }^{33}$ Thus, historical studies tend to work within the short-term framework.

Political memoires tend to take the 'short-term political factor' approach to the collapse of the Soviet Union. They are inclined to play the 'blame-game', pointing fingers at specific political leaders or factions. After all, the former leaders of the Soviet Union were highly invested (emotionally, career-wise, etc.) in the processes that came about in the 1980's. Often, the authors continue to fight the battles that are long over, justifying their ideas and actions to the reader and themselves. In such a way, Anatoly Chernyaev's memoire My Six Years with Gorbachev blames the 'rightists' and 'braking mechanisms' for the failure to transform the country into a liberal democracy effectively. Allegedly, their opposition conflicted with democratic initiatives and led, if indirectly, to collapse. Himself a senior policy aide to Gorbachev, Chernyaev viciously targets the nomenklatura, the conservative leader Yegor Ligachev, and the Soviet mentality which stalled the transformation. For example, he imputes Ligachev with being closely involved, if not directly responsible, for the Nina Andreyeva affair, which damaged the positions and credibility of

\footnotetext{
${ }^{31}$ Stephen E. Hanson, "Gorbachev: The Last True Leninist Believer," in The Crisis of Leninism and the Decline of the Left: The Revolutions of 1989, ed. Daniel Chirot (Seattle: University of Washington Press, 1991), 38.

${ }^{32}$ Kotz and Weir, "The Collapse of the Soviet Union was a Revolution from Above," 163.

33 Ibid, 163-164.
} 
Gorbachev's leadership. ${ }^{34}$ Interestingly, in his own memoire Who Betrayed the USSR?, Ligachev disputes any connection to the affair whatsoever. ${ }^{35}$ Thus, one sees how and why political memoires have a propensity to operate within the 'short-term political factor' framework.

Journalistic accounts tend to blame collapse on the nature of the Soviet 'system'. Drawing upon personal experiences and impressions, they inevitably generalize across cases - which often leads to a synchronic and essentializing writing style. Because journalistic accounts of the time-period are written for a popular Western audience, they also tend to be speculative, sensationalist, and lacking of rigorous, academic analysis. Lenin's Tomb: The Last Days of the Soviet Empire, a book by the Washington Post journalist David Remnick, is a good example of these tendencies. Essentially, Remnick argues that the Soviet Union had a backwards economy, an oppressive political system, a degrading culture, lousy leaders, an imperialist logic, disrespect for religion, a confrontational attitude towards the world, a legacy of violence, a rigidly controlled social life in short, everything that made it 'a bad place.' Hence, it could not possibly have kept living indefinitely. In his study, Remnick uses a lot of sensationalist hearsay that was going around in Moscow at the time; he strongly implies, for example, that the dissident priest Alexander Men was murdered by the KGB - an unproven hypothesis that has since lost credibility. ${ }^{36}$ Remnick also creates a literary mood of darkness and foreboding, illustrating, for example, the Moscow winter as being "endless and foul, a gray slog that began in late September and ended with an even uglier spectacle of late April, known euphemistically as spring." 37 Thus, on the whole, journalistic accounts focus on the nature of 'the system' in explaining the Soviet Union's collapse.

Textbooks and textbook-style studies, for their part, tend to be hesitant in bringing out a specific factor of collapse. The historian Jerry Smith, for example, claims that too little time has passed, and too little has been written, to have established a compelling case for THE cause of Soviet collapse. $^{38}$ Consequently, in his textbook-style book The Fall of Soviet Communism: 1985-91, he takes a thematic approach to factors of collapse, bringing out the most important ones: the economy, Gorbachev's policies, and the nationalities factor. Textbook-style investigations also tend to work within the 'short-term factor' framework. Thus, the historian David Marples, in his book The Collapse of the Soviet Union, 1985-1991, focuses on short-term events in the economic, political, and nationalities spheres.

\section{Conclusion}

In such a way, this paper has argued that historiography is best classified thematically by 'factors of collapse' of the Soviet Union. A chronological examination, for example, would not have been possible because the event is too recent to have established progressive approaches. Likewise, an examination of national approaches (i.e. Western vs. ex-Soviet studies) would not be feasible, given my predominantly Western sources. Accordingly, one can see historiography divided into three themes - the economic, nationalities, and political factors - which are in turn divided into short and long-term schemes. The 'systemic' explanation bridges both specific factor and time frameworks.

\footnotetext{
34 Anatoly S. Chernyaev, My Six Years With Gorbachev, ed. and trans. Robert D. English and Elizabeth Tucker (University Park: Pennsylvania State University Press, 2000), 154-160.

${ }^{35}$ Ligachev, Kmo npedan CCCP? [Who Betrayed the USSR?], 145-154.

${ }^{36}$ Remnick, Lenin's Tomb: The Last Days of the Soviet Empire, 362-364.

${ }^{37}$ Ibid, 53, 324.

${ }^{38}$ Smith, The Fall of Soviet Communism: 1985-91, 2-4.
} 
Furthermore, this essay has contended that there is a correlation between mediums of writing and the 'factor of collapse' they tend to espouse. Figure 1 shows a visual representation of my argument.

Figure 1

ECONOMIC NATIONALITIES POLITICAL

\begin{tabular}{|c|c|c|c|}
\cline { 2 - 4 } SHORT TERM & HISTORICAL STUDIES & HISTORICAL STUDIES & POLITICAL MEMOIRES \\
\cline { 2 - 4 } LONG TERM & POL. SCIENCE STUDIES & POL. SCIENCE STUDIES & POL. SCIENCE STUDIES \\
SYSTEMIC & \multicolumn{3}{|c|}{ JOURNALISTIC ACCOUNTS } \\
\cline { 2 - 4 } & \multicolumn{3}{|c|}{} \\
\end{tabular}

Figure 1 illustrates that political science studies tend to generate long-term explanations of Soviet collapse. Historical studies, in turn, work within the short-term framework. Political memoires focus on the short-term political factor, while journalistic accounts expound the 'systemic' factor. Textbooks, for their part, are hesitant in bringing out a specific factor, but tend to operate in the short-term scheme.

As of yet, there is no consensus as to why the Soviet Union collapsed, though one can expect much more to be written in the future. New archival materials, more comprehensive interviews of both ordinary eyewitnesses and important actors, and rigorous and exhaustive studies that come with the passing of time all promise better explanations. No doubt, it will change the historiographical framework in which studies are situated. For the time being, however, the above analysis adequately classifies historiography into thematic categories, influenced by the medium of writing. 


\section{Bibliography}

Adamova, I. A. and Zinkova, I. M., ed. XXVII свезд КПСС о руководящей роли парии в ускорении развития cmpanb [27th Congress of the CPSU: The Leading Role of the Party in Accelerating the Country's Development]. Moscow: Moscow State University Publishing, 1988.

Bisley, Nick. The End of the Cold W ar and the Causes of Soviet Collapse. New York: Palgrave Macmillan. 2004.

Chernyaev, Anatoly S. My Six Years With Gorbachev. Edited and translated by Robert D. English and Elizabeth Tucker. University Park: Pennsylvania State University Press, 2000.

Cheshko, S. V. "Роль этнонационализма в распаде СССР [The Role of Ethnonationalism in the Break-up of the Soviet Union].” In Tрагедия Великой Аержавъг [Tragedy of a Mighty Power], edited by G. N. Sevostyanov, 443-468. Moscow: Sotsialno-Politicheskaya Misl Publishing, 2005.

Dockrill, Saki R. The End of the Cold War Era: The Transformation of the Global Security Order. London: Hodder Education, 2005.

Duncan, J. S. "The Collapse of the Soviet Union was a Revolution from Below." In The Rise and Fall of the Soviet Union, edited by Laurie Stoff, 145-154. Farmington Hills: Thomson Gale, 2006.

Hanson, Stephen E. “Gorbachev: The Last True Leninist Believer." In The Crisis of Leninism and the Decline of the Left: The Revolutions of 1989, edited by Daniel Chirot, 33-59. Seattle: University of Washington Press, 1991.

Ibos, Caroline. "The Delegitimization of the Soviet System." In The Fall of the Soviet Empire, edited by Anne de Tinguy, 134-153. Boulder: East European Monographs, 1997.

Jowitt, Ken. "The Leninist Extinction In The Crisis of Leninism and the Decline of the Left: The Revolutions of 1989, edited by Daniel Chirot, 74-99. Seattle: University of Washington Press, 1991.

Kedourie, Elie. "Nationalism and the Balance of Power." In End of Empire: The Demise of the Soviet Union, edited by G. R. Urban, 101-132. Washington, D.C.: The American University Press, 1993.

Knight, Robert. Stalinism in Crisis. London, Pluto Press, 1991.

Kotz, David, and Fred Weir. "The Collapse of the Soviet Union was a Revolution from Above." In The Rise and Fall of the Soviet Union, edited by Laurie Stoff, 155-164. Farmington Hills: Thomson Gale, 2006.

Kuznetsov, Victor. “The Economic Factors of the USSR's Disintegration.” In The Fall of the Soviet Empire, edited by Anne de Tinguy, 264-279. Boulder: East European Monographs, 1997.

Ligachev, Yegor. Kmo npedan CCCP? [Who Betrayed the USSR?] Moscow: Algoritm Kniga, 2010.

Marie, Nadine. "From the Failure of a Federal Structure to the Break Between State and Society." In The Fall of the Soviet Empire, edited by Anne de Tinguy, 122-133. Boulder: East European Monographs, 1997.

Marples, David. The Collapse of the Soviet Union, 1985-1991. Harlow: Pearson Education Limited, 2004.

Marples, David. "The Fall of the USSR: The National Dimension and the Role of Ukraine." In Tpazeduя Великой Аержавы [Tragedy of a Mighty Power], edited by G. N. Sevostyanov, 526-542. Moscow: Sotsialno-Politicheskaya Misl Publishing, 2005.

Neimanis, George J. The Collapse of the Soviet Empire: A View from Riga. Westport: Praeger Publishers, 1997.

Pihoya, R. G. "Почему распался CCCP? [Why Did the USSR Break Up?]” In Tрагедия Великой Аержавы [Tragedy of a Mighty Power], edited by G. N. Sevostyanov, 404-422. Moscow: Sotsialno-

Politicheskaya Misl Publishing, 2005. 
Remnick, David. Lenin's Tomb: The Last Days of the Soviet Empire. New York: Random House, 1993.

Smith, Jerry. The Fall of Soviet Communism: 1985-91. New York: Palgrave Macmillan, 2005.

Stankevitch, Z. А. “Соотношение национального и политического факторов в процессе разрушения Союза ССР [The Relationship Between the Political and Nationalities Factors in the Fall of the USSR]." In Tрагедия Великой Аержавы [Tragedy of a Mighty Power], edited by G. N. Sevostyanov, 423-442. Moscow: Sotsialno-Politicheskaya Misl Publishing, 2005.

Walker, Edward W. Dissolution: Sovereignty and the Breakup of the Soviet Union. Oxford: Rowman \& Littlefield Publishers, 2003.

White, Stephen. Communism and Its Collapse. New York: Routledge, 2001. 